\title{
Intercontinental cross-linking of power supply - calculating an optimal power line corridor from North Africa to Central Europe
}

\author{
Katrin Walter ${ }^{*}$ and Stephan Bosch
}

\begin{abstract}
Background: An oversupply of solar radiation in Northern Africa as well as high energy consumption in the economic centers of Central Europe give reason to an international cross-linking of regenerative power supply. A fundamental precondition for this purpose is the development of high-capacity power lines. By this means only, the energy can be economically transferred from the sites of its production to the far-off centers of energy consumption. To date, however, there is little knowledge about how to identify the ideal course of the power line corridor. This study therefore presents a method enabling spatial optimization of the power transfer between North Africa and Europe.

Methods: In this research project, the key spatial factors for the planning of power line corridors were identified and depicted using geographic information systems. Besides focusing on the usage of already existing corridors - e. g., lines running along railways, which could be upgraded to high voltage direct current - attention was paid to the identification of spatial alternatives. In order to obtain insight into these questions, it is necessary firstly to identify centers of power consumption. Secondly, exclusion factors for the planning of power line corridors must be defined, and the corresponding restriction areas need to be visualized.
\end{abstract}

Results: It can be stated that the most favorable way of constructing a power line corridor is through flat barren lands and that it grows more expensive with the extent of the slopes and the share of woodland and utilized agricultural or marine areas passed by the power line. Furthermore, socio-economic cost factors such as labor costs, which are specific for each respective country, lead to a strong spatial diversification.

Conclusions: The presented method enables a technical and ecological structuring of the area of interest, which is the basis for the identification of optimal power line corridors. In retrospect, the project's main challenge was to harmonize the numerous geodata available in greatly differing quality.

Keywords: Power transfer; Energy supply; Power line corridor; High voltage direct current; Desertec; Geographic information systems; Cost distance analysis; Concentrating solar power; Concentrating photovoltaic; Transmediterranean renewable energy cooperation

\footnotetext{
* Correspondence: katrin.walter@geo.uni-augsburg.de

Chair of Human Geography and Geoinformatics, University of Augsburg, Alter Postweg 118, Augsburg 86159, Germany
} 


\section{Background}

\section{Problem statement}

The processes of democratization currently taking place in various African states might serve as a foundation for a safe energy supply on the basis of solar power and might facilitate cooperation with their European neighbors. This is, at least, the hope of the protagonists of the ambitious Desertec concept, who are often suspected of neo-colonialistic ideas behind their vision of 'clean' electricity from the desert [1,2]. This suspicion has been sustained by the fact that only one of the 13 founding companies of the Desertec Industrial Initiative (Dii) - the Algerian company, Cevital - came from a potential producer country. The rest were mainly large German concerns such as E.ON, RWE, Schott Solar, and Siemens, whose interest in the North African continent primarily arose from a calculus of industrial politics [3]. This perspective can be countered by the initiative's conception, which states that the producer countries themselves are to profit from the gross of the value creating chain, since the project focuses on the development of local industries as well as knowledge transfer $[1,2,4]$. Moreover, the biggest share $(80 \%)$ of the produced solar power will remain within the MENA countries [5,6]. Some countries such as Morocco already implement their own solar plans and are also considering the export of power produced thereby. The question remains, however, how and especially along which geographic corridor this percentage of the solar power is to be transferred to the far-off centers of consumption in Central Europe. The achievement of this aim will doubtlessly require the construction of high voltage direct current (HVDC) lines. Using this technology, only $2 \%$ to $4 \%$ of the transmitted energy is lost per 1,000 kilometers $(\mathrm{km})$. Thereby a costeffective regenerative power supply for consumption centers as far as 3,000 to 5,000 km away might be possible. The industrial initiative $\mathrm{Dii} \mathrm{GmbH}$, amongst others, endeavors to identify economic corridors for the construction of HVDC lines. This research project therefore investigated the crucial spatial determinants for the planning of power line corridors and visualized them using geographic information systems (GIS). Firstly, the European centers of power consumption, representing the end-point of the power line corridors, were identified. Secondly, any existing restriction areas for power line corridors were projected onto the regions at interest so that theoretically, suitable corridors emerged. Finally, with additional regard to specifically defined cost factors, the exemplary course of an ideal power line corridor between the power plant facility of Ain Beni Mathar and the consumption center of Paris was calculated and visualized. Paris was chosen for this purpose due to two main reasons. For one, Paris is the greatest power consumption center of Europe. More- over, there is still a chance that France will join a panEuropean energy strategy in the long run. Therefore, our approach may be perceived as an attempt to present an alternative or an opposing concept to the country's nuclear-based power production. The additional benefit of this study is on the one hand a higher resolution of database and consequently a more detailed analysis. On the other hand, technical progress and the locational factor acceptance are included. Technical progress is represented by the possibility to place submarine cables in depths of up to $-3,000$ meters $(\mathrm{m})$ and to construct power lines along higher slopes. The locational factor acceptance is reflected by the distance areas around the restriction areas, e.g., protected areas or land usage like water bodies.

\section{Technological principles}

\section{Concentrating solar power and photovoltaic competing}

In 2003 to 2007, the Trans-Mediterranean Renewable Energy Cooperation, a network of politicians, scientist, and economists, developed the Desertec concept on the initiative of the Club of Rome; in 2009, it was adapted by Munich RE and 12 other companies. One of its aims is the production of regenerative energy in those regions of the Earth with high solar irradiance and to energize both the producing countries and remote centers of energy consumption with it. With respect to the manifold national potentials within the EUMENA region, which is to say Europe, the Middle East, and North Africa, the long-term idea is to integrate all different kinds of renewable energies and to link them via an intercontinental grid [7]. So far, however, the focus remains on the utilization of solar energy. This is mainly due to its great potential and the fact that baseload plants are needed for a reliable energy supply; within $6 \mathrm{~h}$, the deserts of the Earth receive more energy from solar irradiance than all of mankind will consume in the course of one whole year. About 3,000 annual hours of sunshine will yield roughly 2,500 kilowatt hours per square meter (kW h/ $\mathrm{m}^{2}$ ) $[3,8]$. This potential can be efficiently made usable by concentrating solar power (CSP) such as line focusing parabolic troughs and linear Fresnel collectors, as well as point focusing solar towers and dish-Stirling engines [9-11]. These technologies yield the advantage of providing capacity for base load when combined with heat accumulators (e.g., melted salt, concrete) [3,12].

Presently, though, concentrating solar power does not yet have a competitive position against conventionally produced energy; this is expected only in 2030 [13]. Furthermore, photovoltaic technologies constantly aggravate the competitive constraints. This is largely due to the greater marketability of photovoltaic; by the end of the year 2011, an installed capacity of 70 gigawatt (GW) worldwide enabled the industry to achieve economies of 
scale and thereby to reduce the electricity production costs to as little as 10 cents per kilowatt hours (ct/kWh) at sites rich in solar irradiance $(2,500$ kilowatt hours per square meter per year $\left.\left(\mathrm{kWh} / \mathrm{m}^{2} / \mathrm{a}\right)\right)$. In contrast, the global capacity of CSP was only $2 \mathrm{GW}$ - too little to maintain competitiveness by mass production and standardization. The initial costs of CSP technologies are still at 18 to $24 \mathrm{ct} / \mathrm{kWh}$. Parabolic troughs as well as solar towers have consequently lost their original attractiveness and predominance [14] within the desert belts of the Earth [15].

The cost advantage of photovoltaic has come to an extent that companies like Solar Millennium, which were strongly engaged in the CSP market, have been forced to file for insolvency. Many projects that originally built on CSP technologies are now turning to the more profitable photovoltaic. Considering these facts, it seems reasonable that the industrial giant Siemens has withdrawn from the once promising CSP business. After all, the only advantage remaining for solar power plants is their ability to ensure capacity for base load by power storage. Given the development of concentrating photovoltaic modules (CPV) with grades of effectiveness of $40 \%$ and more, even the high effectiveness of CSP technologies is no longer a unique quality. Thus, the triumph of photovoltaic is being reinforced by CPV technologies. Even the Moroccan agency for solar energy (Masen), which so far has mainly been promoting the development of CSP technologies, is now showing great interest in concentrating photovoltaic. At the end of the year 2012, the construction of the first CPV plant in Ouarzazate with a capacity of 160 megawatt (MW) was initialized [3]. Only those countries pursuing aims of industrial politics, which is to say focusing on the aspect of added value within the country rather than on the economic factor of production costs, are still interested in the expansion of solar power facilities. The hope of the CSP industry remains on Saudi Arabia as the country aims at the development of CSP with a capacity of $20 \mathrm{GW}[16,17]$. Yet the energy produced thereby is to be used in the country itself exclusively, so that the fossil energy substituted by it can be fed to the lucrative export business. Thus, the inclusion of the world's leading oil exporter in an intercontinental direct current grid is irrelevant. This strategy explains furthermore why Saudi Arabia even forces the development of nuclear power plants [5].

\section{Direct current transfer}

At the moment, the project of electricity from the desert backed by financially potent companies such as RWE, E. ON, Schott Solar, Flagsol, Abengoa Solar, Deutsche Bank, and HSH Nordbank - focuses its realization on the EUMENA region $[1,18]$. The first solar power plants are already being constructed in North Africa, while not only all of these projects are directly related to Desertec but are also to be perceived as originating from the initiative of single countries. Especially in Morocco which is largely dependent on fossil energy imports - the rate of energy dependency is presently at $97 \%$ - the development is being accelerated, substantiating the solar power plant of Ain Beni Mathar and started implementation in Ouarzazate $[8,19]$. Tunisia is also planning on making use of its great potential in solar irradiance; in 2014, the solar tower plant TuNur is to be erected [17]. According to plan, from 2016, the TuNur shall produce electricity for Italy, which is situated to the North of it. The exact course of the power line corridor is not yet lined out. To date, the only known fact is that the corridor is not to run across Sicily but on sea route between Sicily and Sardinia towards Rome [20].

Independently from the question whether the energetic potential of North Africa will be made usable by solar power or photovoltaic, and independently also from whether the development of these technologies will be pursued by individual countries or by an international cooperation, the goal remains to transfer at least part of the produced energy to Europe. In order to achieve this, HVDC lines running overland as well as through the sea are necessary. This way, the energy can be transferred over great distances with relatively little loss in the form of direct current with voltages of up to 150 kilovolt $(\mathrm{kV})$ and a capacity of $500 \mathrm{MW}$. It is expected that by 2020 , HVDC lines with a voltage of $500 \mathrm{kV}$ and a capacity of 2,000 MW will have become the standard. High-capacity power line corridors already exist today, e.g., the HVDC line NorNed, finished in 2008, a sea line between Norway and the Netherlands, which at a length of $580 \mathrm{~km}$ is the longest of its kind worldwide. In 2011, construction works of BritNed, a HVCD line between Great Britain and the Netherlands were completed [21,22]. Apart from two studies by Deutsches Zentrum für Luft- und Raumfahrt [23,24], the construction of high-capacity power line corridors between North Africa and Europe is unchartered territory both scientifically and technically speaking. Thus, preliminary GIS-supported calculations are necessary. Amongst other determinants, various spatial factors are to be considered. Energy transfer by HVDC can cause tremendous interference with the landscape; accordingly, vulnerable subspaces are to be excluded. Using GIS, preexisting characteristics of the landscape can be cross-linked, and thereby, suitable as well as unsuitable courses of a corridor can be identified.

\section{Methods}

\section{Spatial dimensions of energy transfer}

Besides paying attention to the usage of corridors already existing - e.g., lines running along railways, 
which could be upgraded to high voltage direct current (HVDC) - the GIS analysis focuses on the identification of spatial alternatives. In order to obtain insight into these questions, it is necessary firstly to identify centers of power consumption. Secondly, exclusion factors for the planning of power line corridors must be defined, and the corresponding restriction areas need to be visualized. Four primary location factors will therefore be discussed in detail: conservation areas at land and at sea, land use, bathymetric data, and slopes calculated from relief data.

\section{Centers of power consumption}

The end-points of the power line corridors are represented by centers of energy consumption, which is to say those subspaces with a significantly high consumption of electricity. With the power plant site representing the starting point, the calculation of a point-to-point connection is thereby made possible. The precise endpoints are defined by the coordinates of existing or potential voltage transformations substations, which transform the direct current into alternating current. The analysis at hand focuses on the power consumption centers of the European Union (EU). Within the EU, equal units with a spatial hierarchy exist, the so called Nomenclature of Statistical Territorial Units (NUTS) [25]. The NUTS level 0 represents an EU Member State, which again can be subdivided into three further layers. NUTS level 1 stands for larger regions (3 to 7 million inhabitants, e.g., Bundesländer of Germany or Zones d'études et d'aménagement du territoire - ZEAT - in France), NUTS 2 (0.8 to 3 million inhabitants) stands for medium-sized regions (e.g., Regierungsbezirke in Germany or Régions in France), and NUTS 3 (0.15 to 0.8 million inhabitants) for small regions (e.g., Landkreise or kreisfreie Städte in Germany or Departements in France) [26].

In order to identify centers of power consumption, it is necessary to determine the total electricity consumption on a spatial level as small as possible. By weighing, the consumption rates on the NUTS 3 level can be derived from the data available for NUTS 0. At first, the overall power consumption of an EU member state (NUTS 0 level) is distributed to the sectors of service and industry as well as the domestic sector. The precise quantification of power consumption on NUTS 3 level is obtained from the gross value added in the cases of the

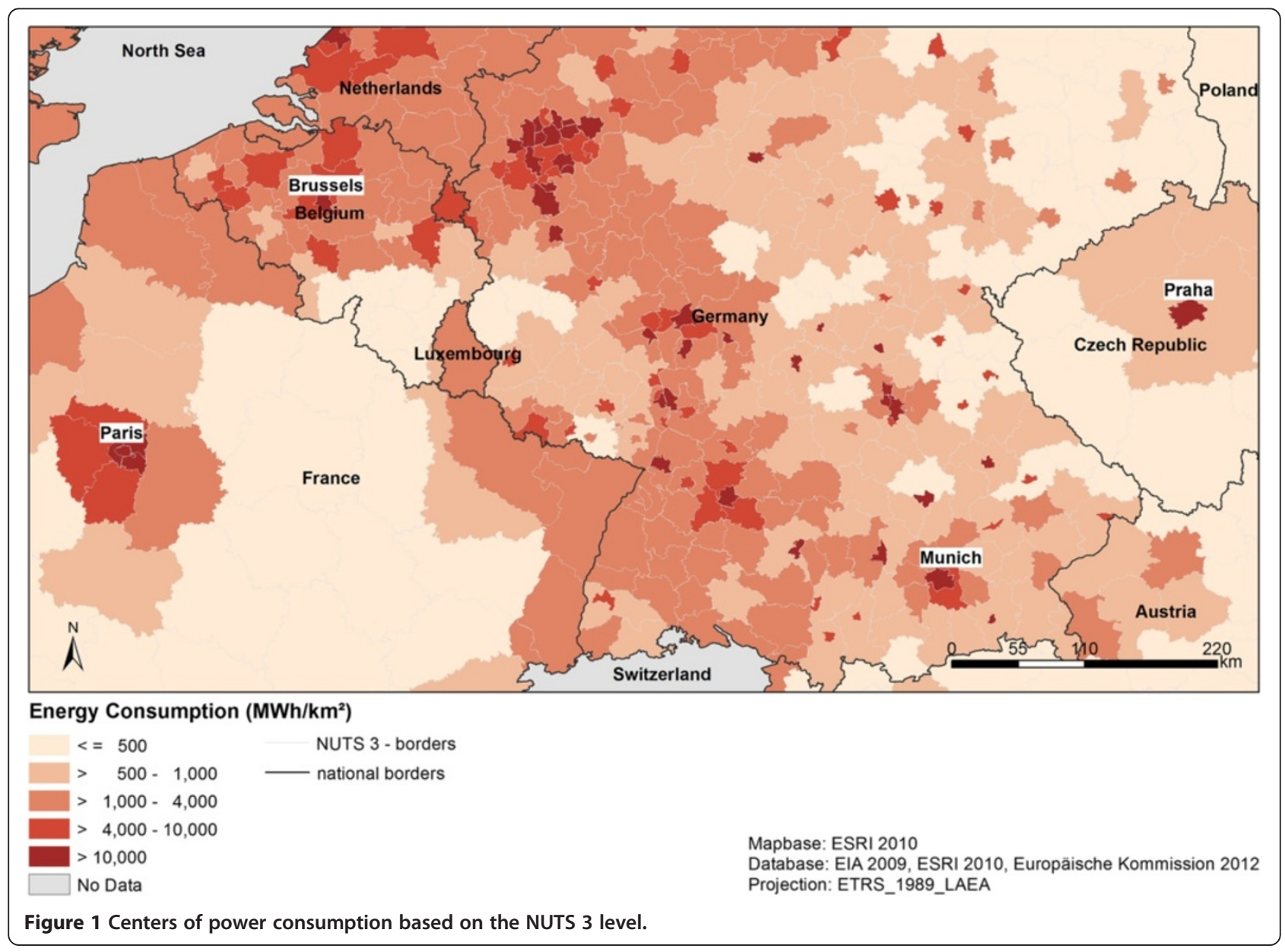


service sector and the industrial sector. In the case of the domestic sector, population numbers serve as the basis of calculation [27]. The presumption is that the ratio of the gross value added of a certain NUTS 3 unit to the overall gross value added (NUTS 0 unit) corresponds to the ratio of power consumption of a NUTS 3 unit to the overall power consumption (NUTS 0). For this reason, the first calculation is that of a NUTS 3 unit economic sector percentage of gross value added of the member state's overall industrial gross value added. The next step is to multiply this figure with the overall industrial power consumption of the EU member state at question. The result is the power consumption of the NUTS 3 unit's industrial sector. The same applies to the service sector. In order to estimate the domestic power consumption, a NUTS 3 unit population percentage of the member state's overall population is calculated. It is then multiplied by the overall power consumption of the domestic sector. Next, the consumption numbers of the three sectors of the NUTS 3 unit are added up so that the exact power consumption of each NUTS 3 unit is obtained. Finally, in order to be able to compare the NUTS 3 units of all member states among each other, the results are normalized to square kilometers (Figure 1).

\section{Exclusion of protected areas}

The environmental impact resulting from the construction of HVDC lines is prohibited in many nature protection areas. It is therefore necessary to exclude ecologically sensible areas from potential HVDC corridors. For the GIS analysis, the Natura 2000 data are of special relevance, a set of data concerning conservation areas of the EU with respect to the Habitats Directive as well as the Birds Directive [28]. Furthermore, data from the World Database on Protected Areas - a joint project of the United Nations Environment Programme and the International Union for Conservation of Nature (IUCN) - are being used. These comprise protection areas at land and at sea. It is then necessary to assess the protection areas for the suitability of the construction of power line corridors. In this context, the key data are those of the IUCN, which include seven international categories of protection (1a, 1b, 2, 3, 4, 5, and 6) [29]. The two last categories (5 and 6), for example, are classified as suitable for the construction of power line corridors.

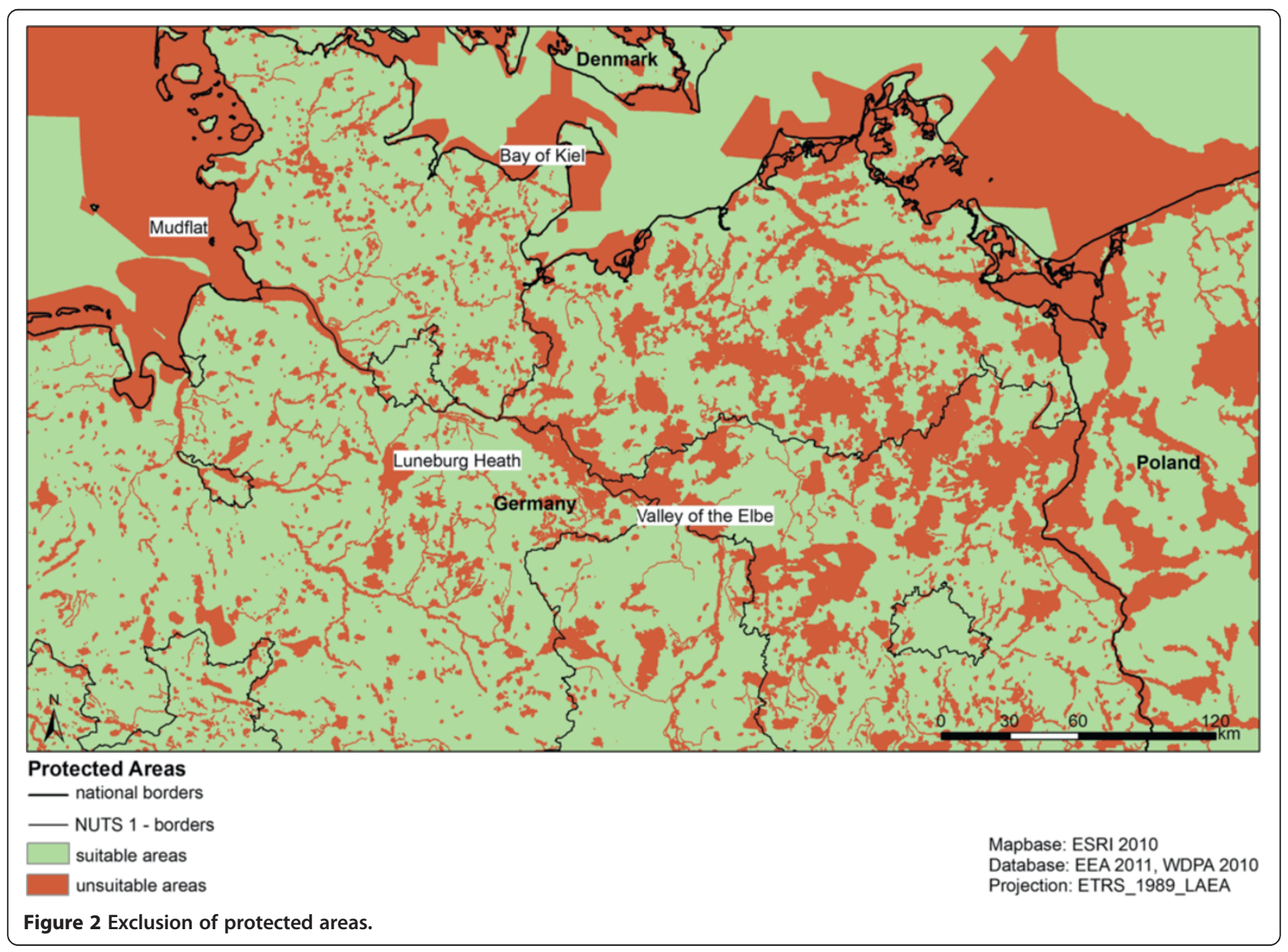


Category 5 stands for the spatial category 'Protected Landscape/Seascape' and category 6 for 'Protected area with sustainable use of natural resources' [30]. With respect to national specificities, natural and regional parks often emerge as protected areas suitable for power line corridors. National parks, nature reserves, and 'protected areas' - e. g. the Mudflat, the Bay of Kiel, the Luneburg Heath, and the Valley of Elbe - are to be unconditionally excluded. In order to ensure a development as sensitive as possible, additional distance areas to the restriction areas are established of $300 \mathrm{~m}$ (Figure 2), which have to be maintained imperatively when constructing the power lines. This buffer zone prevents a corridor from running directly along the borders of the conservation area, thereby provoking public acceptance problems. However, consistent legal regulations for distance areas do not exist, as experience concerning the acceptance of power line corridors is limited as of now.

\section{Analysis of land usage}

In order to be able to determine the landscape's surface structures of the area of interest, data on the land usage are included in the GIS analysis. The data basis is provided by the Corine Land Cover data set of the European Environmental Agency. These land cover data comprise 44 classes of land usage, which can be reduced to five main categories - 'artificial surfaces', 'agricultural areas,' 'forests and seminatural areas,' 'wetlands', and 'water bodies' [31]. Here again, the task is to identify those areas not suitable for the construction of HVDC lines. Since there are no consistent regulations within the EU, the detailed clauses concerning spatial planning of the Federal Republic of Germany are partially transferred on the EU. For example, regions of the category 'continuous urban fabric' [31], e.g., city of Munich, glacier areas of the Alps, and water bodies like the Lake Constance, are excluded. The restriction areas are again expanded by distance areas, e.g., regions of continuous urban fabric with $400 \mathrm{~m}$, industrial or commercial units with $100 \mathrm{~m}$, airports with $2,000 \mathrm{~m}$, and water bodies with $100 \mathrm{~m}$, so that the second mask of restriction areas results (Figure 3).

\section{Bathymetry as an exclusion criterion}

The aim of transporting regenerative power from North Africa to Europe will make it necessary to lay out a

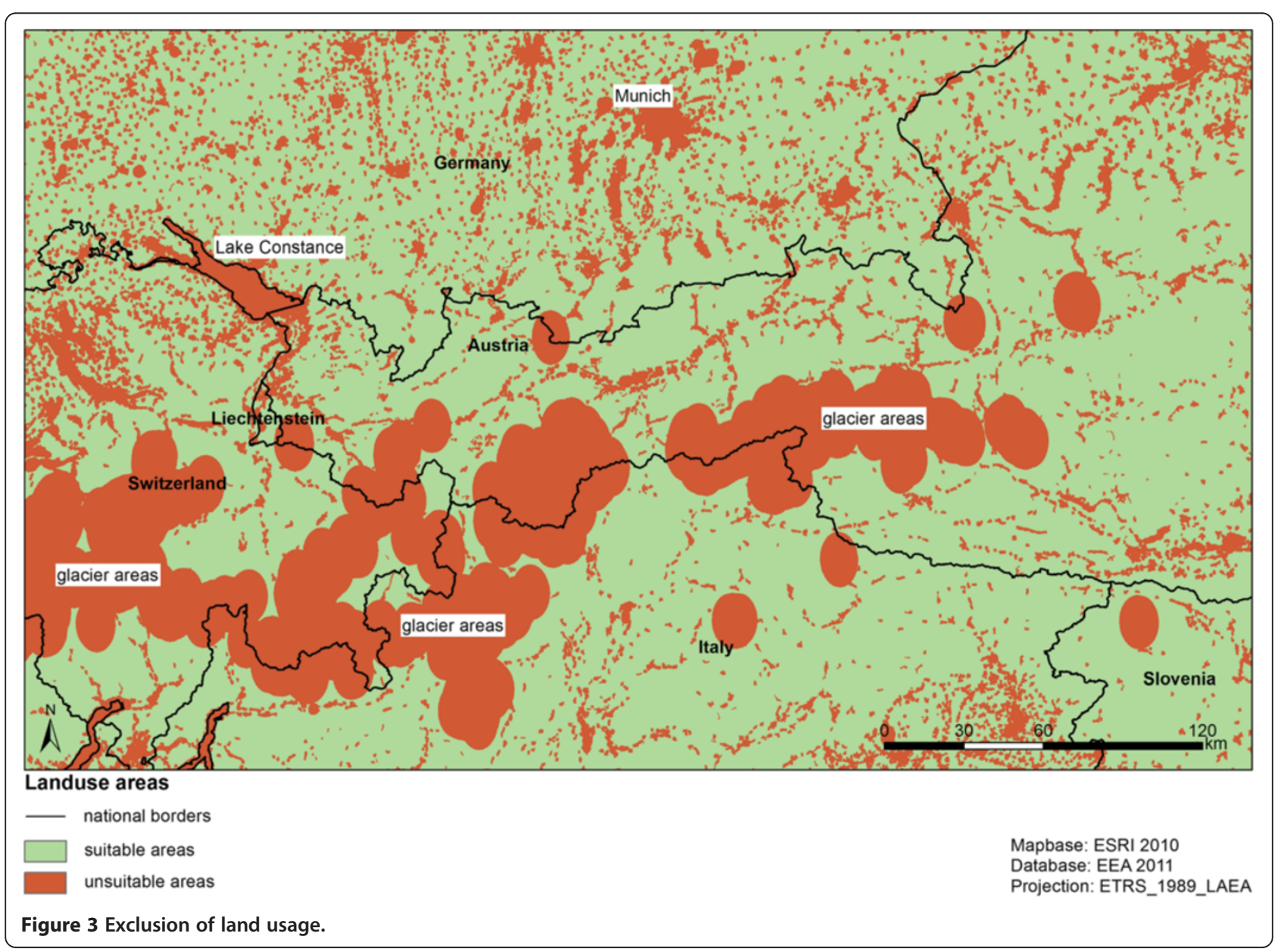


course across the Mediterranean Sea. Although this strategy demands greater operational and monetary expenses, politically instable countries such as Egypt, Israel, Lebanon, and Syria can be avoided. Even though it is not the purpose of this study to rate the political stability of single countries in the context of the GIS analysis, it is still evident that the risk of supply shortfalls increases with the number of transit countries. For this reason, it seems appropriate to decrease the percentage of the terrestrial in favor of the maritime parts of the corridor as much as possible. Yet this does not mean that politically instable countries can be avoided completely. In the context of a transcontinental energy concept, this is not realistic. However, supposedly instable North African countries such as Algeria belong to the OPEC and have been acting as reliable partners in energy matters for a long time. The gas line Gasdotto Algeria Sardegna Italia, whose implementation is scheduled for 2014, may serve as proof of the willingness to cooperate [32]. On the other hand, it is not yet sure whether France will be ready to support the development of power line corridors coming from Spain. After all, the energy company Électricité de France, which is dominated by the government, is mainly interested in forwarding power from its own 58 nuclear plants to Central Europe. The French government resents the cheaper wind and solar power from the South, which would lead to greater instability in the electricity network [22].

To date, the technical possibilities enable the construction of power lines in depths of up to $-2,000 \mathrm{~m}$. However, technical progress until the actual construction of the power lines is to be expected, consequently making the accessibility of greater depths seem realistic. The GIS analysis therefore excludes those parts of the sea deeper than $-3,000 \mathrm{~m}$ (Figure 4).

Remarkably, only few parts of the Mediterranean Sea show depths of more than $-3,000 \mathrm{~m}$. Those few parts, however, are hardly penetrable due to large continuous restriction areas. The Southern part of the Ionic Sea as well as parts of the Libyan Sea, on the one hand, is unsuitable area for the construction of marine power lines. On the other hand, relatively small restriction areas result for the Tyrrhenian Sea and the southeastern Mediterranean Sea (Figure 4). Therefore, construction of power lines in the western Mediterranean Sea is largely

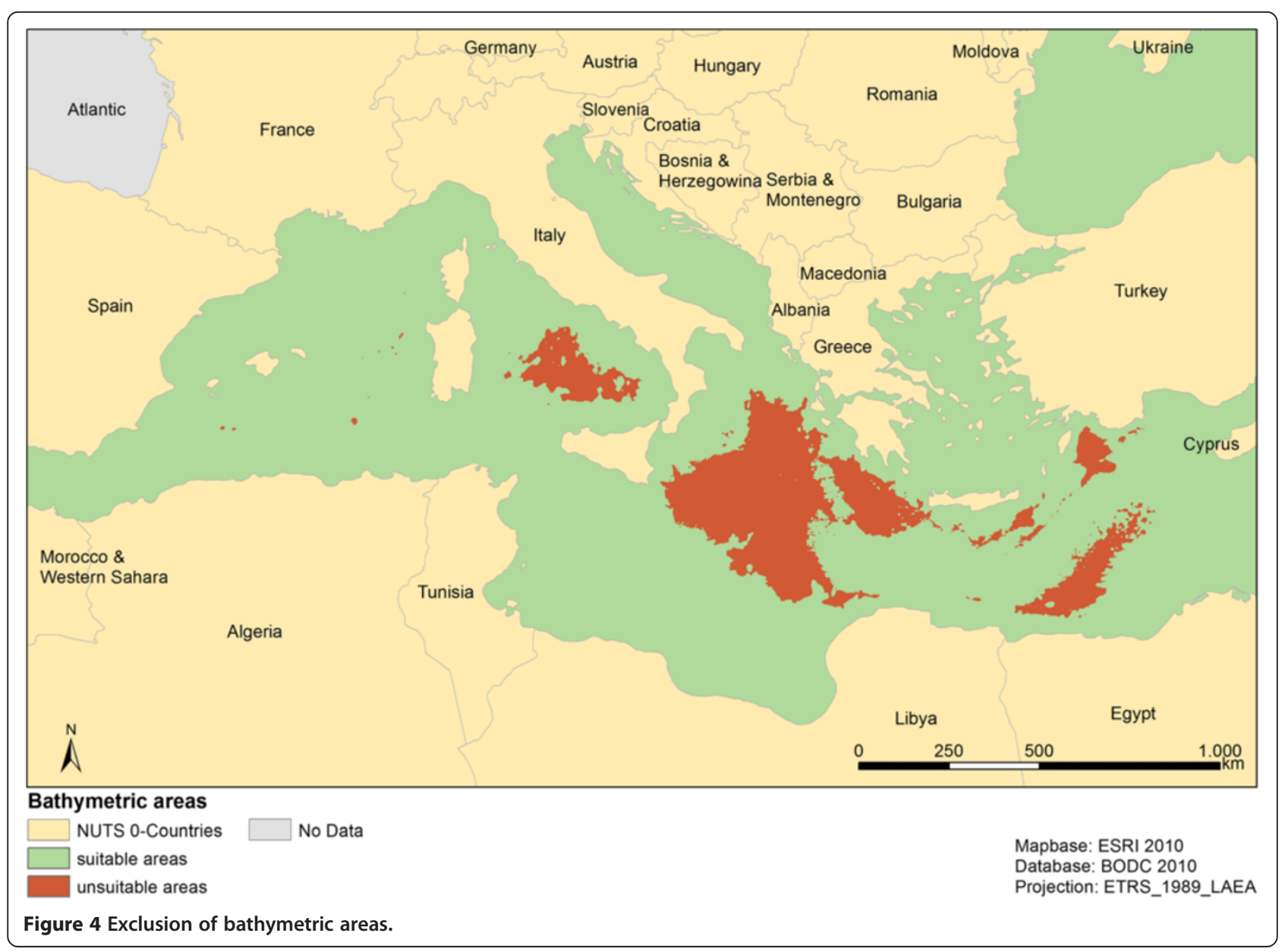


possible, as opposed to the great spatial barriers resulting for the eastern Mediterranean Sea in front of the coasts of Egypt and East Libya. Consequently, a favorable course for the corridor would be across the Street of Gibraltar, since it offers the shortest connection $(14 \mathrm{~km})$ between the African and the European continents. A submarine cable has already been constructed there; however, its capacity is far too small for the expected amount of power. In the face of the lucrative way overland, it seems appropriate to plan a corridor from Algeria or Tunisia across Sardinia and Corse, respectively, to Italy or to choose the way from Tunisia across Sicily towards northern Italy instead.

\section{Critical slopes}

Since courses across steep slopes are to be avoided for power line corridors, it is furthermore necessary to include the criterion of relief energy in the GIS analysis. A slope of more than $100 \%\left(45^{\circ}\right)$ is considered unsuitable (Figure 5), as under such conditions, the construction is impossible or at least too costly. A desirable course would be along fluvial and glacial formed valleys.
Data from the Shuttle Radar Topography Mission [33] serve as the data basis for the identification of exclusion areas. They are available in the reference system WGS84. For this reason, horizontal units are in decimal degrees, whereas surface heights are in meters. In order to still achieve the calculation of slopes between the single grid cells, decimal degrees need to be converted to meters. For this purpose, a converting factor, the socalled z-factor, is applied [34]. Since with increasing geographical latitude where one decimal degree corresponds to a decreasing number of meters, different $\mathrm{z}$-factors result for the different degrees of latitude. Slope calculations are conducted for every region between the 16th and the 60th Northern degrees of latitude.

\section{Results and discussion}

It can be stated that the most favorable way of constructing a power line corridor is through flat barren lands and that it grows more expensive with the extent of the slopes and the share of woodland and utilized agricultural or marine areas passed by the power line. Additionally, socio-economic cost factors such as labor costs, which are specific for each respective country and

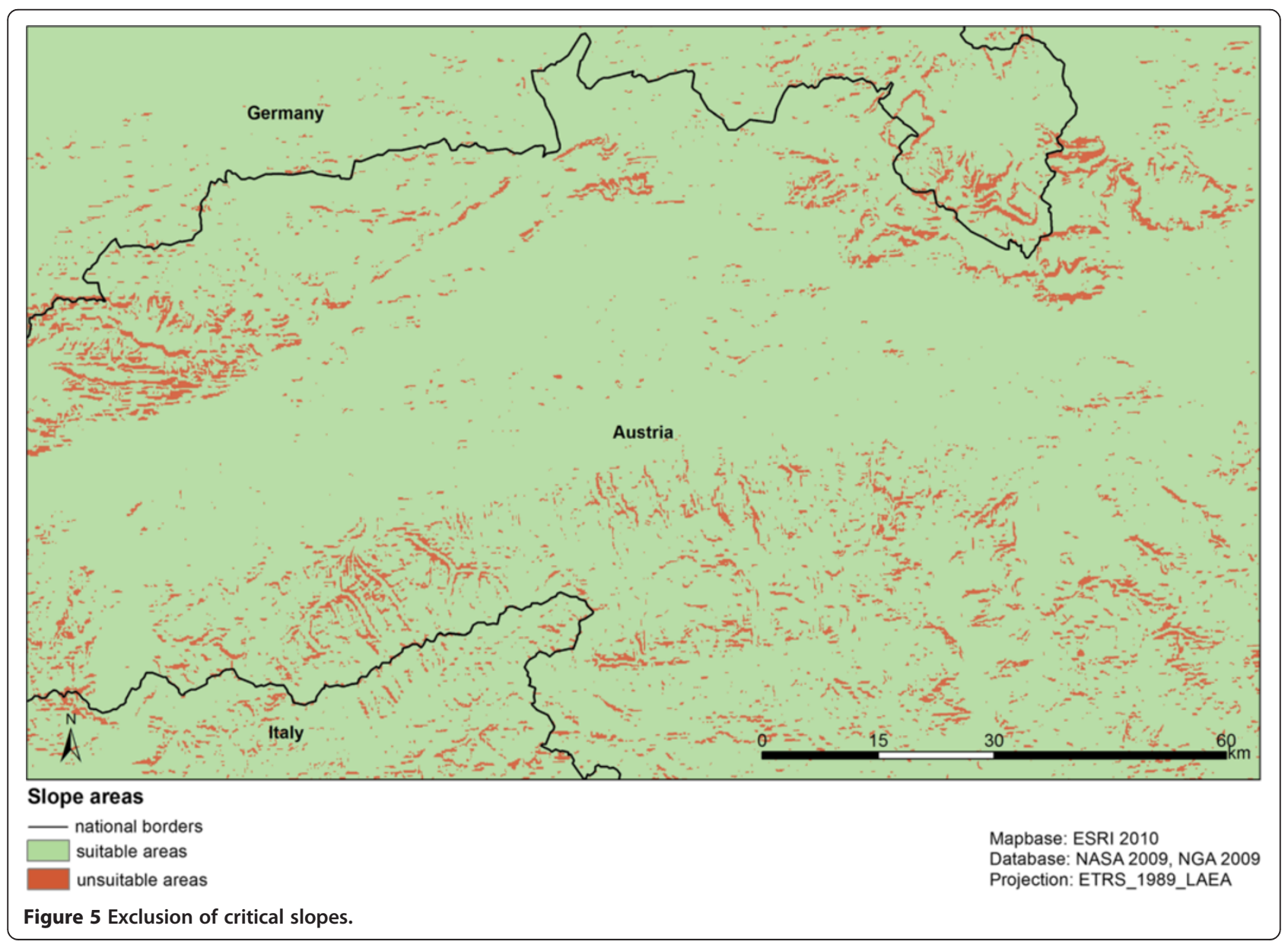


result in a special cost layer, need to be considered (Figure 6). Thus, each pixel will be allocated its data on the key characteristics: overland or by sea, degree of the slope, kind of land usage, and socio-economic background. It is important to mention that the analysis does not include any real costs but rather cost factors, which vary according to different preconditions, e.g., the cost factor ranges from 0.6 for an overhead line up to 2.0 for a submarine cable. It also changes with the slope of the construction site: the higher the slope, the higher the cost factor (range from 1.0 up to 1.5).

Using GIS, with the method of a cost distance analysis, lucrative power line corridors may now be calculated by the overall exclusion area mask and by the cost layer. This is demonstrated by the example of power transfer from Morocco to France (Figure 6). The starting point of the power line corridor is represented by the hybrid power plant in the Moroccan Ain Beni Mathar. As an end-point, Europe's biggest power consumption center Paris - was chosen. Since this city is completely surrounded by restriction areas, the NUTS 3 unit Val-de -Marne in close vicinity to Greater Paris was used as a calculatory basis. Surprisingly, the optimal power line corridor does not run northwards through Spain and the South of France, where natural barriers - such as rivers lead to immense costs. It runs at first through the eastward states of Algeria and Tunisia. Bridging the Mediterranean is greatly facilitated by the islands of Sardinia and Corsica. The corridor continues on to western Austria. The last transit country is Switzerland, before the power line corridor reaches Greater Paris.

\section{Conclusions}

In order to realize further similar projects, each of the national states will have to move towards one another and display the willingness to accept compromises. National interests surely pose hurdles (that need to be taken) on the way to an intercontinental energy system. Nevertheless, the implementation of a cross-national feed-in remuneration - from which not all national states would profit in any case - would be crucially important for the success of intercontinental energy concepts [3]. A main goal would have to be for every partner to be able to draw profit from the project. For example, not only the producer countries but also the transit states might benefit from the remunerations. Under such

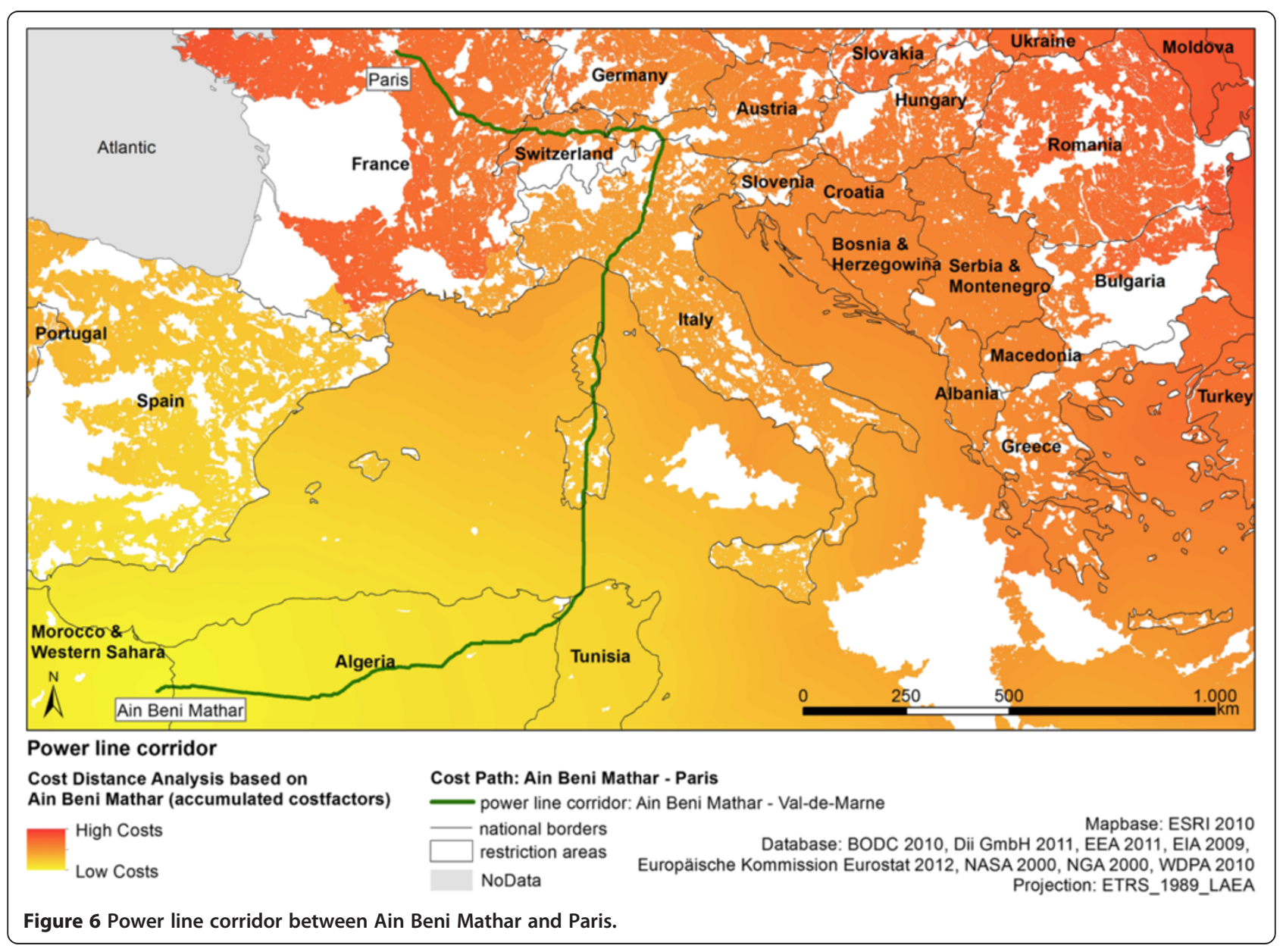


circumstances, Algeria might well serve as a transit country for power produced in Morocco.

Concerning the calculation of further power line corridors, it has to be remarked that information on the power plant sites in North Africa is limited. Consequently, it may be useful to plan courses for corridors starting from European consumption centers towards the sites of power production. Thereby, information might be obtained on useful sites for the construction of future solarthermic or photovoltaic plants. The presented GIS analysis might hence be a tool for the identification of suitable starting points of power line corridors. Beyond doubt, the final implementation of the project will result in a choice of several alternative corridors each of which will be more expensive than the ideal corridor presented here. Therefore, the main goal of the study was to present a method which allows the identification of the economically and ecologically optimal corridor. In order to define alternative corridors, it is necessary to develop scenarios which include locational factors on a microlevel, e.g., local affairs. Yet the study focuses on locational factors on a meso- and macrolevel, e.g., slopes. In any case, the study at hand succeeded in structuring the large area of interest and to give insight into the spatial dimensions of intercontinental power transfer.

\section{Competing interests}

The authors declare that they have no competing interests.

\section{Authors' contributions}

Both authors, KW as well as SB, conceived the study, developed the concept, designed the study, carried out the empirical research, and drafted the manuscript. Both authors read and approved the final manuscript.

\section{Authors' information}

KW is a scientific assistant at the Chair of Human Geography and Geoinformatics at the University of Augsburg. Her most recent research focuses on the application of geographic information systems, renewable energies, and spatial effects of power lines. SB is a scientific assistant at the Chair of Human Geography and Geoinformatics at the University of Augsburg. His most recent research focuses on renewable energies, land use planning, and the application of geographic information systems. He successfully defended his dissertation in June 2012

\section{Acknowledgements}

We thank the reviewers for their helpful comments.

Received: 19 February 2013 Accepted: 2 July 2013

Published: 18 July 2013

\section{References}

1. Desertec Foundation (2009) Red Paper Das Desertec Konzept. Überblick, Berlin, www.desertec.org/downloads/summary_de.pdf. Accessed 3 Jan 2012

2. Löfken J-O (2011) Vorreiter Afrik. In: Technology Review - Das M.I.T.-Magazin für Innovation (1). Spezialheft Energie, Hannover, pp 62-63

3. Schmitt T (2012) Postfordistische Energiepolitiken? Das Desertec-Konzept als Szenario zur Restrukturierung der Energieversorgung in der EUMENARegion. Zeitschrift für Wirtschaftsgeographie 4:244-263

4. Deutsches Zentrum für Luft- und Raumfahrt (DLR) (2009) Concentrating Solar Power for the Mediterranean Region, Stuttgart, http://www.dlr.de/tt/ Portaldata/41/Resources/dokumente/institut/system/projects/MED-CSP_Full_ report_final.pdf. Accessed 20 Aug 2012
5. Löfken J-O (2011) Afrika entdeckt die Sonne. In: Technology Review. Das M.I. T. Magazin für Innovation, Hannover, pp 26-32

6. Dii GH (2012) Desert Power 2050, München, www.dii-eumena.com/fileadmin/ flippingbooks/dp2050_exec_sum_engl_web.pdf. Accessed 15 May 2013

7. Dannenberg M, Duracak A, Hafner M, Kitzing S (2012) Energien der Zukunft - Sonne, Wind, Wasser. Biomasse, Geothermie, Darmstadt

8. Wandler R (2011) Der Sonnenkönig. In: Neue Energie. Das Magazin für Erneuerbare Energien, Berlin, pp 92-95

9. Heuer S (2011) Strom aus der Schussel. In: Technology Review. Das M.I.T. Magazin fur Innovation (1). Spezialheft Energie, Hannover, pp 54-61

10. Kaltschmitt M, Streicher W, Wiese A (2006) Erneuerbare Energien. Systemtechnik, Wirtschaftlichkeit, Umweltaspekte. 4. Aufl, Berlin

11. Quaschning V (2011) Regenerative Energiesysteme - Technologie. Berechnung, Simulation, München

12. Bosch S (2010) Friedmann A, Hilpert M, Jacobeit J, Kunstmann H, Peyke G, Reller A, Schneider T, Thieme K, Timpf S, Wetzel K-F, Wieczorek U (eds) Sauberer Strom aus der Wüste - Der Ausbau von konzentrierenden solarthermischen Systemen zur Sicherung der Energie- und Wasserversorgung in der EUMENA-Region. Geographica Augustana Bd, Augsburg

13. Rentzing S (2011) Im Schatten der Photovoltaik. In: Neue Energie. Das Magazin für Erneuerbare Energien, Berlin, pp 48-51

14. Lessner A (2010) CSP vor neuem Schub. In: Erneuerbare Energien. Das unabhängige Monatsmagazin für die Zukunftsenergien, Hannover, pp 52-55

15. Heup J (2012) Spiegel mit Kratzern. In: Neue Energie. Das Magazin für Erneuerbare Energien, Berlin, pp 83-86

16. Schwarzburger H (2012) Gebündelte Energie. In: Erneuerbare Energien. Das Magazin, Hannover, pp 62-65

17. Schwarzburger H (2012) Voll konzentriert. In: Erneuerbare Energien. Das Magazin, Hannover, pp 56-59

18. Trieb F (2012) Strom aus der Wüste - DLR-Studien zum Projekt Desertec. In: Bührke T, Wengenmayr R (eds) Erneuerbare Energien. Konzepte für die Energiewende, Weinheim

19. BINE Informationsdienst (2011) Solarthermische Kraftwerke: DeutschMarokkanische Zusammenarbeit, Eggenstein-Leopoldshafen, http://www. bine.info/hauptnavigation/publikationen/news/news/solarthermischekraftwerke-deutsch-marokkanische-zusammenarbeit/?artikel=2120. Accessed 6 Nov 2012

20. Tunur (2012) Submarine electricity link. Tunis, New Oxford, http://www tunur.tn/index.php/en/submarine-electricity-link.html. Accessed 18 Dec 2012

21. ABB AB (2008) Submarine cable link, The NorNed HVDC Connection, Norway - Netherlands, Karlskrona, http://www05.abb.com/global/scot/ scot245.nsf/veritydisplay/2402665447f2d054c12571fb00333968/\$file/project \%20norned\%20450\%20kv\%20dc\%20mi\%20sub.pdf. Accessed 3 Jan 2012

22. Zimmermann J-R, Weinhold N (2011) Das Netz wächst zusammen. In: Neue Energie. Das Magazin für Erneuerbare Energien, Berlin, pp 17-23

23. Deutsches Zentrum für Luft- und Raumfahrt (DLR) (2006) TransMediterranean Interconnection for Concentrating Solar Power, Stuttgart, http://www.dlr.de/tt/Portaldata/41/Resources/dokumente/institut/system/ projects/TRANS-CSP_Full_Report_Final.pdf. Accessed 18 Oct 2012

24. Deutsches Zentrum für Luft- und Raumfahrt (DLR) (2009) Characterisation of Solar Electricity Import Corridors from MENA to Europe, Stuttgart, www.dlr. de/Portaldata/41/Resources/dokumente/institut/system/publications/ Solar_import_DLR_2009_07.pdf. Accessed 4 Feb 2013

25. Europäische Union (EU) (2003) Verordnung (EG) Nr. 1059/2003 des Europäischen Parlaments und des Rates vom 26. Mai 2003 über die Schaffung einer gemeinsamen Klassifikation der Gebietseinheiten für die Statistik (NUTS), http://eur-lex.europa.eu/LexUriServ/LexUriServ.do?uri=OJ: L:2003:154:0001:0041:DE:PDF. Accessed 3 Jan 2012

26. Europa (2008) Zusammenfassungen der EU-Gesetzgebung, http://europa eu/legislation_summaries/regional_policy/management/g24218_de.htm. Accessed 5 Jan 2012

27. Leuthold F, Weigt HV, Hirschhausen C (2008) ELMOD - A Model of the European Electricity Market, Dresden, http://papers.ssrn.com/sol3/Delivery. cfm/SSRN_ID1169082_code857256.pdf?abstractid=1169082\&mirid=3. Accessed 4 Jan 2013

28. European Environment Agency (EEA) (2011) Natura 2000 data - the European network of protected sites, Copenhagen, http://www.eea.europa. eu/. Accessed 6 Jan 2012

29. International Union for Conservation of Nature (IUCN) (2012) IUCN Protected Area Management Categories. Gland, http://www.iucn.org/about/ 
work/programmes/gpap_home/gpap_quality/gpap_pacategories/. Accessed 5 Jan 2013

30. WWF Deutschland (2008) Hintergrundinformation Internationale Schutzgebiets-Kategorien der IUCN, Berlin, http://www.wwf.de/downloads/ publikationsdatenbank/ddd/29437/. Accessed 8 Jan 2012

31. Deutsches Zentrum für Luft- und Raumfahrt (DLR) (2012) Corine LandcoverBodenbedeckungsdaten für Deutschland, Weßling, http://www.corine.dfd. dlr.de/intro de.html

32. Galsi (2011) Gasdotto Algeria Italia via Sardegna, Milano, http://www.galsi. com/. Accessed 14 May 2013

33. National Aeronautics and Space Administration (NASA) (2005) Shuttle Radar Topography Mission., Washington, http://www2.jpl.nasa.gov/sttm/dataprod. htm. Accessed 23 Jan 2012

34. ESRI (2007) Mapping Center, Setting the Z factor parameter correctly, Redlands, http://blogs.esri.com/Support/blogs/mappingcenter/archive/2007/ 06/12/setting-the-z-factor-parameter-correctly.aspx. Accessed 8 Jan 2012

doi:10.1186/2192-0567-3-14

Cite this article as: Walter and Bosch: Intercontinental cross-linking of power supply - calculating an optimal power line corridor from North Africa to Central Europe. Energy, Sustainability and Society 2013 3:14.

\section{Submit your manuscript to a SpringerOpen ${ }^{\circ}$ journal and benefit from:}

- Convenient online submission

- Rigorous peer review

- Immediate publication on acceptance

- Open access: articles freely available online

- High visibility within the field

- Retaining the copyright to your article

Submit your next manuscript at $\gg$ springeropen.com 